\title{
Soil carbon stock in olive groves agroforestry systems under different management and soil characteristics
}

\author{
Camilla Bateni · Maurizio Ventura (1) - Giustino Tonon · Andrea Pisanelli
}

Received: 15 March 2018/Accepted: 7 February 2019/Published online: 21 March 2019

(C) The Author(s) 2019

\begin{abstract}
The atmospheric concentrations of greenhouse gases have increased to unprecedented levels during last decades, raising concerns about their effect on climate change. Agriculture and land use change play an important role in atmospheric $\mathrm{CO}_{2}$ emission and fixation, especially by affecting the soil carbon (C) storage. In this context, agroforestry systems (AFSs) could play an important role contributing to climate change mitigation. Given the importance of olive cultivation in the Mediterranean region, it is important to investigate soil $\mathrm{C}$ stock in olive groves, and to assess which agronomic practices could improve the soil $\mathrm{C}$ stock in these systems. For this reason, a study was conducted in different olive groves, including conventional and organic management, and a typical silvopastoral AFS. Furthermore, an abandoned olive grove and nearby forest were examined as a comparison. Soil samples were collected in each farm and analysed for $\mathrm{C}$ content and physicochemical characteristics. This study indicates that, irrespective of the management, olive groves in the Umbria region of Italy are characterised by a high level of soil $\mathrm{C}$ stock if compared to those growing in
\end{abstract}

C. Bateni · M. Ventura $(\bowtie) \cdot$ G. Tonon Faculty of Science and Technology, Libera Università di Bolzano, 39100 Bolzano, Italy

e-mail: maurizio.ventura@unibz.it

\section{A. Pisanelli}

Institute of Research on Terrestrial Ecosystems, National

Research Council, Porano, Italy other areas and to forest ecosystems, indicating that the practices adopted in the area are not negatively affecting soil C storage. A slightly lower soil C stock was measured in the silvopastoral AFS in comparison to the other farms, while high soil $\mathrm{C}$ stock was associated with the use of pomace, suggesting that this practice can be used to further increase soil C stock in olive orchards.

Keywords Carbon storage $\cdot$ Silvopastoral $\cdot$ Olive pomace $\cdot$ Mediterranean $\cdot$ Italy

\section{Introduction}

The atmospheric concentrations of the greenhouse gases (GHGs), carbon dioxide $\left(\mathrm{CO}_{2}\right)$, methane $\left(\mathrm{CH}_{4}\right)$, and nitrous oxide $\left(\mathrm{N}_{2} \mathrm{O}\right)$ have all increased to unprecedented levels since 1750 due to human activities, such as fossil fuel combustion and land use change (IPCC 2013). Among the effects related to the increase of atmospheric GHGs concentration, the increase in temperature is without any doubt the most known and evident.

As recognised by the Paris Agreement, the conservation and the enhancement of carbon (C) sinks such as soils, provides a prospective way of mitigating the increasing atmospheric concentration of $\mathrm{CO}_{2}$ and it should be included among the future actions of all the 
Parties (UNFCCC 2015). It has been estimated that by the use of improved agricultural practices, soils could sequester around $20 \mathrm{Pg} \mathrm{C}$ in 25 years, i.e. more than $10 \%$ of the global anthropogenic emissions (FAO 2015).

In this framework, agriculture has important effects in the atmospheric $\mathrm{CO}_{2}$ emission and fixation (Janssens et al. 2003; Kutsch et al. 2010), indeed it is estimated that agriculture is still responsible for about one-third of GHG emissions (Gilbert 2012). However, by improving agricultural practices and restoring degraded soils it is possible to help to mitigate climate change by reducing emissions from agriculture and other sources and by improving $\mathrm{C}$ storage in plant biomass and soil (Rioux 2012).

Agroforestry systems (AFSs) have a high potential for climate change mitigation (IPCC 2000; Fornara et al. 2018) due especially to their role in reducing $\mathrm{C}$ emissions and promoting $\mathrm{C}$ sequestration in soil and biomass, and have been recommended for Europe through the European Rural Development Council regulation 1698/2005 (Mosquera-Losada et al. 2011). Nevertheless, the extent of $\mathrm{C}$ sequestration in AFSs depends on a number of site-specific factors, e.g. soil characteristics, especially silt and clay content (Takimoto et al. 2009; Haile et al. 2010), species composition, plant age, rotation length, and system management (Nair et al. 2009). In fact, estimates of $\mathrm{C}$ sequestration in AFSs are highly variable, ranging from less than one to several $\mathrm{Mg}$ of $\mathrm{C} \mathrm{ha}^{-1}$ year $^{-1}$ (Schroeder 1994; Gordon and Thevathasan 2006; Udawatta and Jose 2011).

Agroforestry systems are of great importance in many regions of the Mediterranean area, such as in central Italy or the south-western Spain and Portugal. In these regions, the cultivated trees define the agricultural landscape and represent a consistent component within a variety of arable or pastoral land uses (Eichhorn et al. 2006). Olive trees in particular form a continuous landscape element in many parts of southern Europe, with different crops sown between the trees: cereals, vegetables, fodder legumes or fodder grasses (Eichhorn et al. 2006). In Umbria region the extra-virgin olive oil chain involves about 30,000 farms growing olive trees in about 27,000 ha, and 270 oil mills. The regional production of olive oil is about $1.5 \%$ of the total national production. The protected designation of origin (PDO) Umbria extra virgin olive oil, with an annual average production of
600 tons, is about the $7 \%$ of the total national production of PDO oils (Regione Umbria 2017). In the Italian regions of Umbria and Lazio, silvoarable systems are widely adopted, covering about 20,000 ha in total. These systems include olive trees that are commonly intercropped with cereals or fodder legumes (Eichhorn et al. 2006). The main function of trees is olive oil production, but timber can be used to obtain firewood and high quality wood (Pisanelli et al. 2006).

The C sink function of olive cultivation has received until now little attention, notwithstanding its diffusion in the Mediterranean region, where it covers some 9.5 million ha (Nieto et al. 2013). There is still little knowledge regarding the fixation of atmospheric $\mathrm{CO}_{2}$ of olive groves and its role in climate change (Proietti et al. 2014). However, some studies report a $\mathrm{C}$ sequestration potential for fruit tree ecosystems similar to that of forests, ranging from 240 to $1250 \mathrm{~g} \mathrm{C} \mathrm{m}^{-2}$ year $^{-1}$ (Montanaro et al. 2017a). Olive production involves several management practices that require energy and resources, potentially reducing the environmental benefits gained from $\mathrm{C}$ sequestration in soil. Nevertheless, the abandonment of the soil tillage and the use of sustainable practices such as amendments with organic material or mulching of crop residues can increase soil $\mathrm{C}$ content to levels comparable or above those under native vegetation (Nieto et al. 2010; Montanaro et al. 2017b). Therefore, the olive production chain has significant environmental impacts, depending on the techniques and practices used (Proietti et al. 2014).

Considering the importance of olive oil production in Italy and southern Europe and the scarcity of data on SOC content in olive groves, it is important to go further in the research concerning the role of these systems as $\mathrm{C}$ sinks. For this reason, a study has been conducted to measure soil $\mathrm{C}$ stock in different olive groves in Umbria region, including a conventionally managed farm where organic soil amendments with olive pomace are performed, an organic management systems, an abandoned olive grove currently under recovery, and a silvopastoral agroforestry system, where olive cultivation is combined with sheep grazing. The sampled farms were selected to provide a representative sample in terms of soil type, olive tree cultivars, agricultural practices and soil management systems used in the area. A forested area located in one 
of the sampled farms was sampled to provide a comparison with potential natural vegetation.

\section{Materials and methods}

Site description

The survey was carried out in four farms in the surroundings of Orvieto, central Italy $\left(42^{\circ} 43^{\prime} 00^{\prime \prime} \mathrm{N}\right.$, $12^{\circ} 07^{\prime} 00^{\prime \prime} \mathrm{E}$ ) (Fig. 1). According to the KöppenGeiger climate classification, the climate of the area is temperate with hot summer (Kottek et al. 2006). Information concerning agricultural practices (soil management, tree age and density, fertilisation practices, irrigation, pruning wood management) used in the farms have been collected by farmers' interviews. The different farms are identified using acronyms on the base of the management practices used.

Bagni farm - high density, organically managed (HO)

$\mathrm{HO}$ farm is located in the municipality of Orvieto, in the mid-west side of the region at an altitude of $310 \mathrm{~m}$ a.s.1. Leccino, Frantoio and Moraiolo are the main olive cultivars. Most of the trees in the farm are 40 years old and tree density is 300 trees $\mathrm{ha}^{-1}$. The farm was abandoned for at least 6 years and then recovered in 2005, since when regular management practices has been applied. The farm is organically managed and no irrigation is applied. Natural grass cover is kept between the tree rows and periodically mown. Spontaneous wild asparagus plants are present near the trees and harvested for on-farm consumption. In part of the olive groves, fertilisation with cow manure (about $45 \mathrm{Mg} \mathrm{ha}^{-1}$ year $^{-1}$ ) is applied since about 10 years, and followed by surface tillage. In this farm, soil sampling was conducted in two 40 years old olive groves, one amended (a) and the other unamended with manure.

\section{Bubbola farm - high density, conventionally manged, fertilised (HCF)}

The farm is located in the Municipality of Porano, in the south-west side of Umbria region at an altitude of $431 \mathrm{~m}$ a.s.l. Olive cultivation in the farm started in 1959 and the plantation was renewed in 2002. The main olive cultivars are Itrana, Ravece, Bosana, Leccino and Moraiolo. Olive groves are drip-irrigated and planted at a density of 400 trees $\mathrm{ha}^{-1}$. The farm is conventionally managed. The soil is amended with $4 \mathrm{Mg} \mathrm{ha}^{-1}$ of olive pomace, performed every year since 2004 (Vicente-Vicente et al. 2016). Fertilisation with $0.4 \mathrm{Mg} \mathrm{ha}^{-1}$ of dried poultry manure pellets and additionally some mineral fertiliser (nitrogen,

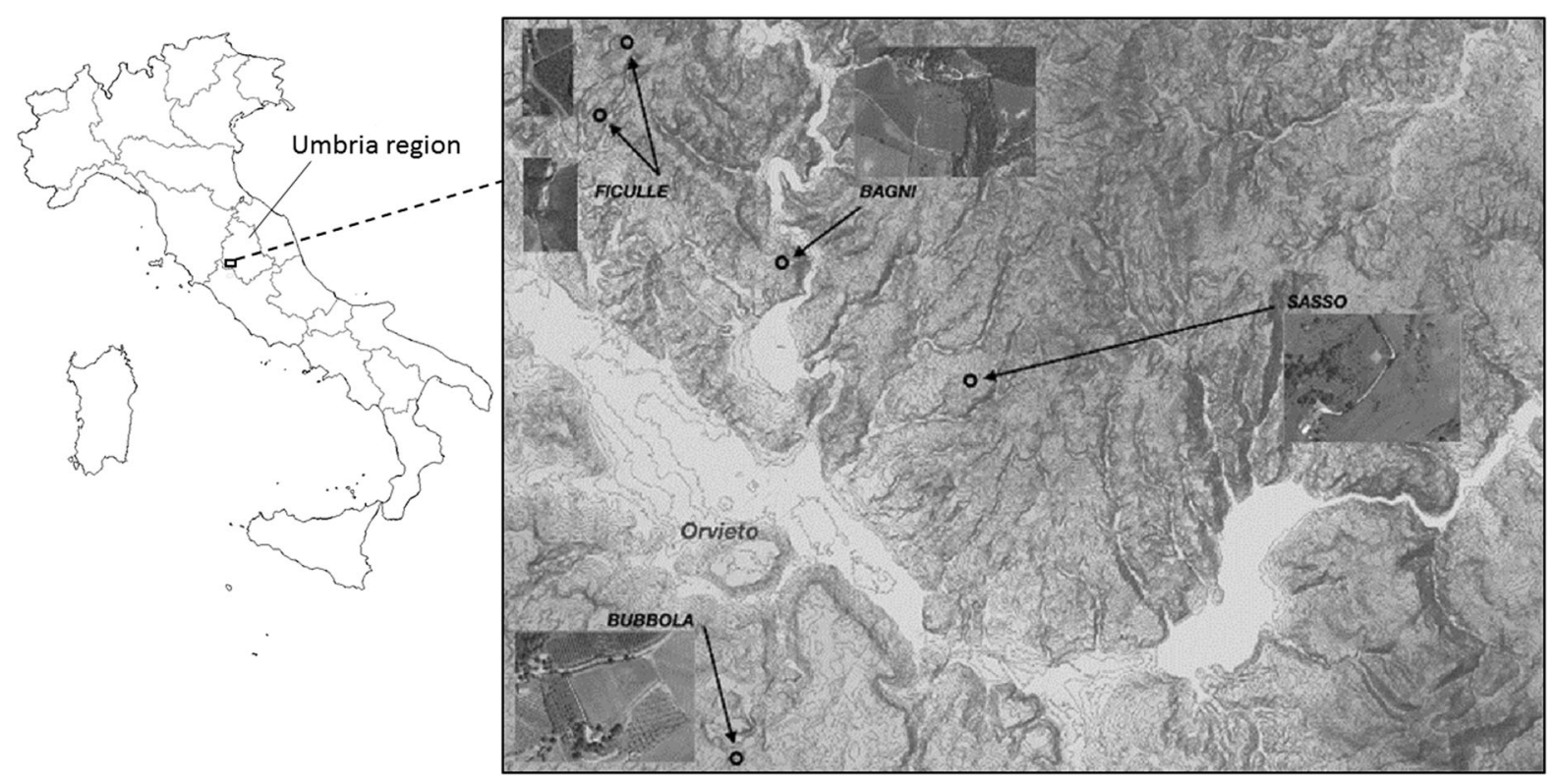

Fig. 1 Location of the farms in the area around Orvieto, Umbria Region, Central Italy 
phosphorus and sulphur) is performed occasionally. The soil under the trees is managed through rotation of different crops (alfa-alfa, wheat, barley and red clover), which are periodically shredded (once a year) and left on the field as mulching.

\section{Il Sasso farm - low density, extensive silvopastoral system (ESP)}

The farm is located in the Municipality of Orvieto, in the mid-west of the region at an altitude of $377 \mathrm{~m}$ a.s.l. The farm combines extensive olive groves (about 35 years old) with a low tree density (135 trees ha ${ }^{-1}$ ) and sheep grazing for milk production in a typical example of silvopastoral system, since the establishment of the plantation. Animals freely graze the whole day and small amounts of hay is provided as feed during the winter period. No other feeds are provided and no chemical products are used in the farm. Olive groves are occasionally fertilised with dry sheep manure, in addition to the fresh manure provided by the grazing animals. The land includes an area covered by broadleaf wood dominated by oaks, which was managed as coppice until about 35 years ago, then left mainly unmanaged (only some trees are occasionally removed to obtain fuelwood for the farm). In this farm, soil samples for the $\mathrm{C}$ stock determination were collected in the olive grove and in the wooded area (f).

\section{Ficulle farm - intensive, organic (IO)}

The farm is located in the municipality of Ficulle, midwest of Umbria, at an altitude of $390 \mathrm{~m}$ a.s.l. Olive trees (Frantoio, Leccino and Moraiolo cultivars) have been managed intensively for about 20 years, from 1950 to 1970 . Since 2015 , only organic farming practices have been performed. Trees are more than 50 years old, and plantation density is 230 trees $\mathrm{ha}^{-1}$. Natural grass cover is kept between the tree rows and is periodically mown. This farm includes an area where olive groves have been recovered one year before sampling, after about 5 years of abandonment with partial regrowth of spontaneous vegetation (r). Soil samples for $\mathrm{C}$ stock determination were collected in both the productive olive grove and in the recovered area.
Soil sampling and analysis

In spring 2017, five to ten soil samples were collected in each site, both on tree rows and inter-rows using a 2.5-cm diameter auger (Eijkelkamp, Giesbeek, The Netherlands), at $0-30 \mathrm{~cm}$ and $30-60 \mathrm{~cm}$ depth. Additional samples were taken in each site for soil bulk density determination (Al-Shammary et al. 2018), using a 4.8-cm split soil sampler (Eijkelkamp, Giesbeek, The Netherlands). Soil samples were sieved ( $2 \mathrm{~mm}$ mesh), dried at $40{ }^{\circ} \mathrm{C}$ in an oven and finely ground before analysis. Organic $\mathrm{C}$ and total $\mathrm{N}$ content in the collected soil samples were determined with an Elemental Analyzer (Flash 2000 Organic Elemental Analyzer, ThermoFisher Scientific). Soil samples were pre-treated with $6 \mathrm{M} \mathrm{HCl}$ to eliminate inorganic C. Specifically, an aliquot of soil containing about $100 \mu \mathrm{g}$ of organic $\mathrm{C}$ was weighed into silver capsules, then a few drops of $\mathrm{HCl}$ were added to each aliquot (Tonon et al. 2010). The capsules were then heated at $80{ }^{\circ} \mathrm{C}$ on a heating late to dry them before analysis.

For each site and soil layer $(0-30 \mathrm{~cm}$ and 30 $60 \mathrm{~cm}$ ), soil C stock was calculated on hectare basis as follows (Lee et al. 2009):

$$
\begin{aligned}
\mathrm{C}_{\text {stock }}\left(\mathrm{t} \mathrm{ha}^{-1}\right)= & \mathrm{C}(\%) / 100 \times \rho_{\text {soil }}\left(\mathrm{t} \mathrm{m}^{-3}\right) \\
& \times 3000\left(\mathrm{~m}^{3} \mathrm{ha}^{-1}\right),
\end{aligned}
$$

where $\mathrm{C}$ is the organic $\mathrm{C}$ content $(\%)$; $\rho_{\text {soil }}$ is the soil bulk density $\left(\mathrm{t} \mathrm{m}^{-3}\right)$ and 3000 is the soil volume $\left(\mathrm{m}^{3}\right)$ in one hectare $(30 \mathrm{~cm}$ soil layer). The total $\mathrm{C}$ stock for the entire $0-60 \mathrm{~cm}$ soil layer has been then obtained as the sum of the C stocks in the $0-30 \mathrm{~cm}$ and $30-60 \mathrm{~cm}$ layers.

Soil $\mathrm{pH}$ was determined, for each soil sample and layer, in $\mathrm{H}_{2} \mathrm{O}$ (1:2.5) with a $\mathrm{pH}$-meter (Basic 20, Crison instruments, Barcellona, Spain). Soil texture was determined with the Bouyoucos (Hydrometer) method (Bouyoucos 1962), according to the USDA classification.

\section{Statistical analysis}

Data were subjected to analysis of variance (ANOVA), followed by orthogonal comparisons to assess the influence of farm management and soil characteristics on soil $\mathrm{C}$ stock, with a confidence level of $5 \%$. Homogeneity of variance was checked before analysis using Levene's test. Angular transformation 
was applied to percentage data of $\mathrm{C}$ and $\mathrm{N}$ content before the ANOVA. Linear regression analysis was used to relate soil $\mathrm{C}$ stock to soil $\mathrm{pH}$, and soil $\mathrm{C}$ and $\mathrm{N}$ content. The relations were tested separately for each soil layer $(0-30$ and $30-60 \mathrm{~cm})$ and for the total examined soil profile $(0-60 \mathrm{~cm})$.

\section{Results}

The soil of the examined sites was classified as Loam or Sandy clay loam (Table 1). No significant effect of texture on soil $\mathrm{C}$ stock was detected. In both the examined soil layers, the $\mathrm{pH}$ value in the HCF farm was significantly lower than in the other olive groves (Table 2). No significant differences were observed in soil $\mathrm{pH}$ between the other olive groves (Table 2); however, the forested area in the ESP farm showed a lower $\mathrm{pH}$ than the adjacent olive grove in the same farm (Table 2). No significant relations were detected between soil $\mathrm{pH}$ and soil $\mathrm{C}$ stock in the examined sites, when data were considered separately for the two sampled soil layers (Fig. 2). However, a significant relation was found between total soil $\mathrm{C}$ stock and the average $\mathrm{pH}$ value of the whole soil profile $(0-60 \mathrm{~cm})$ (Fig. 2).

In all the examined sites, a higher $\mathrm{C}$ content was found in the upper soil layer $(0-30 \mathrm{~cm})$ (Table 2). In this layer, SOC content of olive groves ranged from $1.23 \%$ in $\mathrm{HCF}$ farm to $0.64 \%$ in the amended olive grove of $\mathrm{HO}$ farm (Table 2). The $\mathrm{C}$ content was particularly high in the forested area, significantly different from the other sites (Table 2). Among the olive groves, the lowest values were observed in the amended organic olive groves of $\mathrm{HO}$ farm and in the recovering area of IO farm (Table 2). The differences observed between the other olive groves were not significant. In the deeper soil layer $(30-60 \mathrm{~cm})$, significantly higher values were observed in the HCF farm and in the forested area of ESP farm (Table 2).

Also for $\mathrm{N}$ content, higher values were detected in the upper soil layer $(0-30 \mathrm{~cm})$ in comparison with the lower one (30-60 cm) (Table 2). In the upper layer, the highest concentration of $\mathrm{N}$ was detected in the forested area, while the lowest one was found in the organic amended olive grove of HO farm (Table 2). In the $30-60 \mathrm{~cm}$ layer, the forest site showed again the highest $\mathrm{N}$ content, while no significant differences were detected between the different olive groves (Table 2). A significant relation was found between $\mathrm{C}$ and $\mathrm{N}$ content in both layers $(0-30 \mathrm{~cm}$ and $30-60 \mathrm{~cm})$ (Fig. 3).

In all the examined sites, the soil organic $\mathrm{C}$ stock was higher in the surface layer $(0-30 \mathrm{~cm})$ in comparison to the deeper one $(30-60 \mathrm{~cm})$ (Table 3). In the surface layer, the highest $\mathrm{C}$ stock was detected in the forested area (70.5 Mg C ha ${ }^{-1}$ ) (Table 3). The HO farm showed instead the lowest value $(35.8 \mathrm{Mg} \mathrm{C}$ $\mathrm{ha}^{-1}$ ) (Table 3). In the 30-60 cm layer different trends can be noticed (Table 3): HCF farm was characterized by the highest value of soil $\mathrm{C}$ stock (33.3 $\mathrm{Mg} \mathrm{C} \mathrm{ha}^{-1}$ ) together with $\mathrm{HO}$ farm $\left(27.5 \mathrm{Mg} \mathrm{C} \mathrm{ha}^{-1}\right.$ in the not amended soil and $31.7 \mathrm{Mg} \mathrm{C} \mathrm{ha}{ }^{-1}$ in the amended one) (Table 3). No significant differences were noticed between the remaining farms in this soil layer (Table 3).

On average, the total soil $\mathrm{C}$ stock in the examined sites was $73 \pm 10 \mathrm{MgC} \mathrm{ha}^{-1}$. The highest value was observed in the forested area $\left(88 \pm 9 \mathrm{Mg} \mathrm{C} \mathrm{ha}^{-1}\right)$, followed by $\mathrm{HCF}$ farm amended with pomace $\left(80 \pm 4 \mathrm{Mg} \mathrm{C} \mathrm{ha}^{-1}\right.$ ) (Table 3). All the other olive groves showed a lower soil $\mathrm{C}$ stock, with no significant differences among the values (Table 3 ).

Table 1 Soil texture in the examined farms

\begin{tabular}{lllll}
\hline Site & Av. silt $(\%)$ & Av. clay $(\%)$ & Av. sand (\%) & Texture \\
\hline ESP & 23 & 22 & 54 & Sandy clay loam \\
HO & 16 & 27 & 57 & Sandy clay loam \\
HCF & 29 & 21 & 49 & Loam \\
IO & 27 & 25 & 47 & Loam \\
\hline
\end{tabular}

ESP extensive, silvopastoral system, $H O$ high density, organic, $H C F$ high density, conventionally managed, fertilised, $I O$ intensive, organic 
Table 2 Soil $\mathrm{C}$ stock in the examined sites

\begin{tabular}{|c|c|c|c|c|c|c|}
\hline \multirow[t]{2}{*}{ Depth $(\mathrm{cm})$} & \multicolumn{2}{|l|}{$\mathrm{pH}$} & \multicolumn{2}{|l|}{$\mathrm{N}(\%)$} & \multicolumn{2}{|l|}{$\mathrm{C}(\%)$} \\
\hline & $0-30$ & $30-60$ & $0-30$ & $30-60$ & $0-30$ & $30-60$ \\
\hline $\mathrm{HO}(\mathrm{a})$ & $8.19 \pm 0.05 \mathrm{a}$ & $8.33 \pm 0.05 \mathrm{a}$ & $0.08 \pm 0.01 \mathrm{~d}$ & $0.08 \pm 0.01 \mathrm{~b}$ & $0.64 \pm 0.09 \mathrm{~d}$ & $0.57 \pm 0.04 \mathrm{~b}$ \\
\hline $\mathrm{HO}$ & $8.05 \pm 0.04 \mathrm{a}$ & $8.16 \pm 0.07 \mathrm{ab}$ & $0.13 \pm 0.01 \mathrm{bc}$ & $0.07 \pm 0.01 \mathrm{~b}$ & $1.14 \pm 0.08 \mathrm{bc}$ & $0.53 \pm 0.01 \mathrm{~b}$ \\
\hline $\mathrm{HCF}$ & $6.97 \pm 0.09 \mathrm{c}$ & $6.96 \pm 0.1 \mathrm{c}$ & $0.13 \pm 0.01 \mathrm{bc}$ & $0.1 \pm 0.01 \mathrm{~b}$ & $1.23 \pm 0.07 \mathrm{~b}$ & $0.88 \pm 0.07 \mathrm{a}$ \\
\hline IO & $8.16 \pm 0.03 \mathrm{a}$ & $8.28 \pm 0.1 \mathrm{a}$ & $0.15 \pm 0.01 \mathrm{~b}$ & $0.09 \pm 0.01 \mathrm{ab}$ & $1.11 \pm 0.08 \mathrm{bc}$ & $0.57 \pm 0.1 \mathrm{~b}$ \\
\hline IO (r) & $8.39 \pm 0.03 \mathrm{a}$ & $8.53 \pm 0.02 \mathrm{a}$ & $0.1 \pm 0.02 \mathrm{~cd}$ & $0.08 \pm 0.02 \mathrm{~b}$ & $0.89 \pm 0.09 \mathrm{bc}$ & $0.51 \pm 0.1 \mathrm{~b}$ \\
\hline ESP & $8.17 \pm 0.04 \mathrm{a}$ & $8.35 \pm 0.04 \mathrm{a}$ & $0.12 \pm 0.01 \mathrm{bc}$ & $0.07 \pm 0.01 \mathrm{~b}$ & $1.02 \pm 0.07 \mathrm{c}$ & $0.47 \pm 0.04 \mathrm{~b}$ \\
\hline $\operatorname{ESP}(f)$ & $7.48 \pm 0.29 b$ & $7.91 \pm 0.14 \mathrm{~b}$ & $0.2 \pm 0.02 \mathrm{a}$ & $0.11 \pm 0.01 \mathrm{a}$ & $2.27 \pm 0.33 \mathrm{a}$ & $1.06 \pm 0.08 \mathrm{a}$ \\
\hline
\end{tabular}

Different letters identify significant differences within the same soil layer, for $p<0.05$

$H O$ high density, organic, $H C F$ high density, conventionally managed, fertilised, $I O$ intensive organic, ESP ESP: extensive, silvopastoral system, (a) manure amended, (r) recovered, (f) forest area

Fig. 2 Relation between soil $\mathrm{pH}$ and soil $\mathrm{C}$ stock of the two sampled soil layers (0-30 $\mathrm{cm}$ and 30-60 $\mathrm{cm})$

(a) and for the whole examined soil profile $(0-60 \mathrm{~cm})(\mathbf{b})$
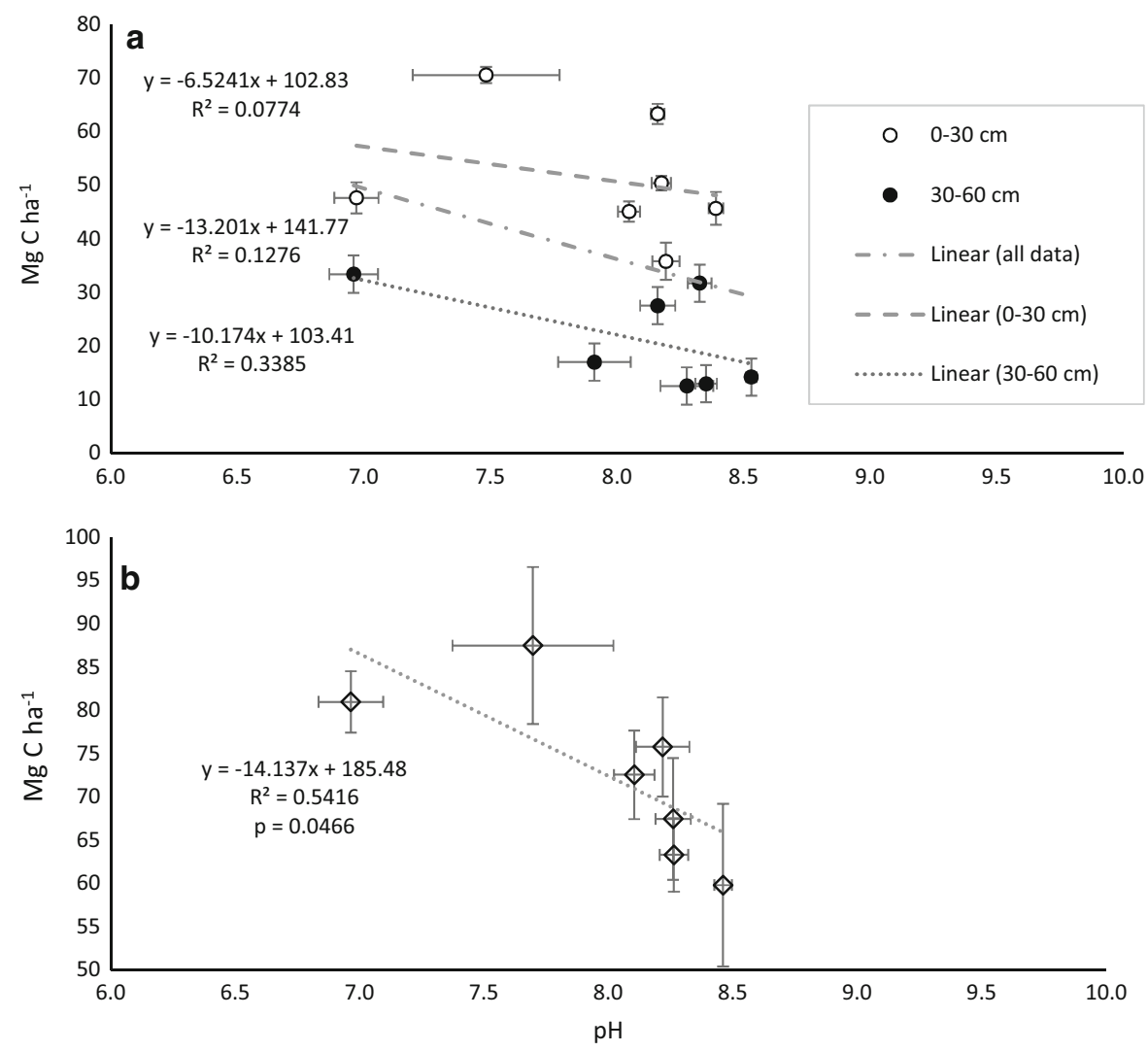

\section{Discussion}

The comparison of soil C stocks among different sites is always difficult, due to the number of factors affecting it, which are not only connected to the farm management but also to the particular microclimatic conditions and soil characteristics. For this reason, the examined farms have been selected in an area that is relatively homogeneous in terms of soil type and climatic conditions.

However, the high number of farms present in the studied area allowed the selection of a representative 
Fig. 3 Relation between $\mathrm{C}$ and $\mathrm{N}$ content $(\%)$ in the upper soil layer $(0-30 \mathrm{~cm})$ and the lower soil layer (30-60). The regression line refers to the data from both soil layers pooled together

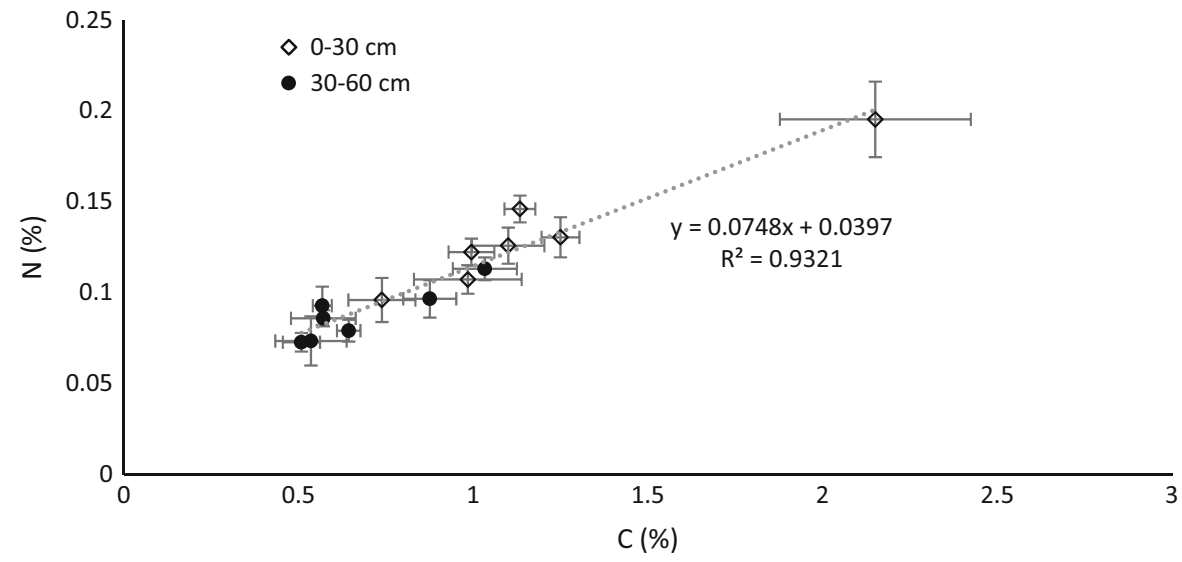

Table 3 Soil $\mathrm{C}$ stock in the examined sites

\begin{tabular}{llll}
\hline Farm & \multicolumn{2}{l}{ Soil C stock $\left(\mathrm{Mg} \mathrm{C} \mathrm{ha}^{-1}\right)$} \\
\cline { 2 - 4 } Depth (cm) & $0-30$ & $30-60$ & Total (0-60) \\
\hline HO (a) & $36 \pm 6 \mathrm{a}$ & $32 \pm 4 \mathrm{c}$ & $68 \pm 7 \mathrm{c}$ \\
HO & $45 \pm 5 \mathrm{bc}$ & $27 \pm 2 \mathrm{bc}$ & $72 \pm 5 \mathrm{c}$ \\
HCF & $47 \pm 2 \mathrm{a}$ & $33 \pm 3 \mathrm{bc}$ & $80 \pm 4 \mathrm{~b}$ \\
IO & $63 \pm 5 \mathrm{ab}$ & $12 \pm 2 \mathrm{ab}$ & $75 \pm 6 \mathrm{c}$ \\
IO (r) & $48 \pm 9 \mathrm{abc}$ & $14 \pm 3 \mathrm{abc}$ & $62 \pm 9 \mathrm{c}$ \\
ESP & $50 \pm 4 \mathrm{~b}$ & $13 \pm 1 \mathrm{bc}$ & $63 \pm 4 \mathrm{c}$ \\
ESP (f) & $71 \pm 9 \mathrm{a}$ & $17 \pm 1 \mathrm{a}$ & $88 \pm 9 \mathrm{a}$ \\
\hline
\end{tabular}

Different letters identify significant differences within the same soil layer for $p<0.05$

$H O$ high density, organic, $H C F$ high density, conventionally managed, fertilised, $I O$ intensive organic, ESP extensive, silvopastoral system, (a) manure amended, (r) recovered, (f) forest area

sample of many different soil management and agricultural practices that can affect soil $\mathrm{C}$ stock in olive cultivation. In fact, a large variability in SOC stock was observed among the examined sites, especially in the deeper layers. This variability is likely due to the different practices adopted in the farms, even if the influence of some characteristics such as $\mathrm{pH}$ cannot be totally excluded. Few studies are available examining the $\mathrm{C}$ stock in olive groves in Italy, notwithstanding the diffusion of these systems in the Mediterranean region. Mohamad et al. (2016), who examined $\mathrm{C}$ stock in organic and conventional olive cultivation systems, report $63.69 \pm 9.94 \mathrm{Mg} \mathrm{C}^{-1}$ SOC in the organically managed olive grove and $54.58 \pm 1.16 \mathrm{Mg} \mathrm{C} \mathrm{ha}^{-1}$ in the conventional one.
Parras-Alcántara and Lozano-García (2014) also present some data concerning the total SOC stock in olive groves in Mediterranean rangelands, ranging from $43.75 \pm 5.11 \mathrm{Mg} \mathrm{ha}^{-1}$ in Cambisol under conventional tillage, to $95.4 \pm 8.16 \mathrm{Mg} \mathrm{ha}^{-1}$ in Luvisol under organic farming. Nieto et al. (2013) present a mean SOC of $22.9 \pm 8.0 \mathrm{Mg} \mathrm{C}^{-1}$ for olive groves under conventional tillage. In comparison to data from these previous studies, the average soil $\mathrm{C}$ stock of olive groves examined in the surroundings of Orvieto resulted to be quite high $\left(72 \pm 9 \mathrm{Mg} \mathrm{ha}^{-1}\right)$.

In agreement with other studies (Lozano-García and Parras-Alcántara 2014), the soil C content decreased with depth, approximately halving in the lower layer $(0.66 \%)$ in comparison to the upper layer (1.21\%). Notwithstanding this difference, the lower soil layer contained a significant amount of $\mathrm{C}$, that should be taken into account to avoid an underestimation of the total soil $\mathrm{C}$ stock. The relevant soil $\mathrm{C}$ stock found in the deeper soil is also due to the higher bulk density of this soil in comparison to the shallower one. In the forested areas, the higher $\mathrm{C}$ stock of the upper layer could be related to the accumulation of leaf litter on the surface. In the olive groves, soil management practices such as ploughing and mulching could have led to a diminishing of the organic matter in the upper soil layer, with a consequent accumulation in the underlying one. This could explain why in some of the examined orchards the $\mathrm{C}$ stock in the deeper soil layer was comparable to that measured in the shallower one.

In the previously abandoned olive grove of IO farm, the $\mathrm{C}$ stock was not significantly different from that measured in the managed olive grove in the same farm 
and from those in the other examined farms, neither in the shallower nor in the deeper soil layer. Atallah et al. (2015) analysed the SOC in olive orchards at different times from abandonment (from 6 years to several decades) in the Mediterranean Lebanon, finding that soil $\mathrm{C}$ stock increased, as a result of abandonment, by 18.6 $\mathrm{Mg} \mathrm{C} \mathrm{ha}^{-1}$ on average. However, a lower $\mathrm{C}$ stock was found in the most recently abandoned sites in comparison to those abandoned for over two decades (Atallah et al. 2015). Therefore, it is likely that only 5 years of abandonment were not enough to observe a significant difference in the recovering area of the IO farm in comparison to the productive area in the same farm.

Soils in natural forest ecosystems are characterised by a high $\mathrm{C}$ density. Land use change, particularly the conversion to agricultural ecosystems, usually depletes the soil C stock, and SOC content of agricultural soils is usually lower than their potential capacity (Lal 2005). The depletion of SOC observed in agricultural soils can be attributed to numerous factors, including changes in soil moisture and temperature accelerating organic matter decomposition; increased decomposability of crop residues; tillageinduced perturbations; reduction in physical protection of the soil organic matter, and increase in soil erosion (Lal 2005). In fact, residues from olive oil production and pruning wood are usually removed from the field and often burned, resulting in a general loss of $\mathrm{C}$ from the system. For example, Nieto et al. (2010) report that land use change from native vegetation to tilled olive groves can lead to a decrease in SOC and $\mathrm{N}$ contents, due mainly to continuous tilling and a concomitant decrease of $\mathrm{C}$ input to soil.

Other studies show on the contrary that SOC stock in olive orchards may reach levels comparable or above those under native vegetation. For example, Lozano-García et al. (2016) found that land use change from Mediterranean evergreen oak woodlands to olive groves led to an increase of SOC stock by $22.3 \%$. Analyses performed in the present study present similar results, indicating that average SOC stock in the examined olive groves was comparable to that of forest soils. In fact, estimates form the national forest inventory report an average SOC stock of $78.7 \mathrm{Mg} \mathrm{ha}^{-1}$ in forests of Umbria region (INFC 2005). This is confirmed also by the small difference observed in the present study between SOC of the olive grove and the adjacent forest soil in the ESP farm. In particular, the observed difference was only due to the higher SOC stock in the shallower soil layer of the forest soil. In the deeper soil layer, the $\mathrm{C}$ stock was higher in the forest than in the olive grove in the same farm, but lower than in the olive groves in the $\mathrm{HO}$ and $\mathrm{HCF}$ farms. This indicates that practices performed in the area are not negatively affecting SOC stock.

The different soil management practices have been performed in the examined farms since 10 years at least, so this study can be considered as indicative of their effect on SOC in the short or medium term. However, more time is needed to assess the dynamic of SOC over time, using repeated sampling or the chronosequence approach, to be able to draw conclusion on the effect of these practices on soil $\mathrm{C}$ stock in the long term.

In the present study, the manure amendment applied in the HO farm did not increase significantly the soil C stock. On the contrary, the high soil C stock measured in the HCF farm could be due to the olive pomace amendments performed in this field. Amendment with composted or un-composted olive pomace is a common practice in Mediterranean woody crops (Vicente-Vicente et al. 2016) and has been reported to increase of SOC. For example, García-Ruiz et al. (2012), who found that composted olive mill pomace application for 4-16 years increased soil organic matter (SOM) from 2.1 to 8.5 times in comparison to unamended soils. Brunetti et al. (2005) also noticed a significant increase of SOC after the addition of olive pomace, to durum wheat (Triticum turgidum L.) fields in Mediterranean environments. The present study is in agreement with these results, confirming the positive effect of pomace amendments on SOC stock in olive groves. However, concerns have been raised on this practice because of the high phenolic content of olive pomace and its potential phytotoxicity (Roig et al. 2006) even if also positive effects on soil microbial activity and biomass have been reported (Saviozzi et al. 2001; García-Ruiz et al. 2012). Therefore, further studies are foreseen to investigate more deeply effects of this practice not only on soil C stock but also on soil quality in the long term.

It should be mentioned that the lower soil $\mathrm{pH}$ found in the HCF farm could have affected the $\mathrm{C}$ stock in addition to the pomace amendments. Liao et al. (2016) report that SOM density increases over the $\mathrm{pH}$ range of 4.2-6.5, and decreases sharply over the $\mathrm{pH}$ range of 
6.5-9.2. In fact, soil $\mathrm{pH}$ largely influences microbial activity and thereby soil organic matter formation and decomposition (Liao et al. 2016). However, also microbial decomposition can decrease soil $\mathrm{pH}$ in the long term, especially because of nitrification process and the release of organic acids (Killham 1994). This could explain why in the present study, the areas with the lowest $\mathrm{pH}$ (forested area and HCF farm) were the ones with the highest soil $\mathrm{C}$ stock, and the significant relation found between the total SOC stock and the soil $\mathrm{pH}$ (Fig. 2). The lower soil pH value in the HCF farm could be also related to the different geological substrate, since this farm is located on a volcanic area while all the other farms are characterised by a sedimentary substrate. On the other hand, it should be considered that higher SOC content in the abovementioned soils could have lowered the $\mathrm{pH}$, so the lower $\mathrm{pH}$ could be the result of the higher SOC stock instead of its cause. This could explain also the lower soil $\mathrm{pH}$ in the forest area. A direct influence of pomace treatment on soil $\mathrm{pH}$ could also be possible, because of the acidic $\mathrm{pH}$ (about 5) which characterises the olive pomace (GAL 2013). A similar effect has been in fact observed by other authors (Piotrowska et al. 2006; López-Piñeiro et al. 2008; García-Ruiz et al. 2012).

Additionally, we noticed that HCF farm has also one of the highest value of total $\mathrm{N}$. This is in agreement with López-Piñeiro et al. (2008), García-Ruiz et al. (2012) and Cabrera et al. (2005) who found a significant increase in the soil organic $\mathrm{N}$ after application of olive mill pomace. This result suggests that organic $\mathrm{N}$ in the composted olive mill pomace is very resistant to mineralization, and is highly retained in the soil (García-Ruiz et al. 2012). Therefore, short- and long-term application of olive mill pomace to olive grove soil seems to have positive effects on its physical, chemical, and biochemical properties, because of to the high organic matter content of this material (García-Ruiz et al. 2012).

The $\mathrm{C}$ stock in the silvopastoral AFS was slightly lower than in the other different olive groves. The observed difference is almost significant $(p=0.074)$, indicating that sheep grazing in this particular climatic conditions could induce the reduction of soil C stock. In this specific case, no particular devices and techniques (e.g. crop rotation, improvement of soil fertility, attention to livestock stocking rate) were applied by the farmer, while it is known that some of these practices can strongly affect soil $\mathrm{C}$ stock. It should be also mentioned that other studies have found that silvopastoral AFSs are more efficient in increasing the C-stock when compared to the continuous grazing system in absence of trees (Nair et al. 2009; Da Rocha Junior et al. 2014). Therefore, future studies extending the comparison to different silvopastoral AFSs and sheep-grazed pastures without the presence of trees are foreseen, to understand the real SOC sequestration potential of these systems.

\section{Conclusions}

This study indicates that, irrespective of the management, olive groves in the Umbria region of Italy are characterised by a high level of soil $\mathrm{C}$ storage, if compared to those growing in other areas and to forest ecosystems, indicating that the practices adopted in the area are not negatively affecting SOC stock. Therefore, maintaining olive cultivation would be recommended in the region in order to maintain the high soil $\mathrm{C}$ stock in the area, avoiding its return to atmosphere as a consequence of land use conversion to arable land or to the adoption of different soil management practices such as soil tillage.

To maintain or further increase soil $\mathrm{C}$ stock in olive orchards, the most interesting practice among those used in the area seems to be the use of pomace as soil amendment. This practice could also represent a partial solution to the problem of the disposal of residues from olive oil production for farms and small companies in the area.

The slightly lower soil $\mathrm{C}$ stock measured in the silvopastoral system in comparison to the other farms indicated that this particular system could not be the most suitable to increase soil $\mathrm{C}$ content. Further studies comparing different silvopastoral AFSs with traditional pasture management practices are foreseen, to understand better the effect of this AFS on soil C stock. Furthermore, this study shows that, in the evaluation of the soil $\mathrm{C}$ stock in perennial woody crops, it is important to extend the analysis also to the deeper soil layers, as they can store a considerable amount of $\mathrm{C}$.

Acknowledgements This study was conducted as part of the SustainFARM Project. This project has received funding from the European Union's Horizon 2020 research and innovation programme, Grant Agreement No. 652615, under the frame of FACCE SURPLUS (Sustainable and Resilient agriculture for 
food and non-food systems). Furthermore, this work has been supported by the Open Access Publishing Fund of the Free University of Bolzano. We thank the farmers for all the information provided about the management practices used in their farms; Pierluigi Paris, Marco Lauteri and the other CNR collaborators, as well as the interns of Unibz Joel de Happy Towoua and Lorenzo Panizzon for the help provided during soil samples collection, management and preparation and Prof. Michael Bahn from Univeristy of Innsbruck for the advice provided during the paper preparation.

Open Access This article is distributed under the terms of the Creative Commons Attribution 4.0 International License (http:// creativecommons.org/licenses/by/4.0/), which permits unrestricted use, distribution, and reproduction in any medium, provided you give appropriate credit to the original author(s) and the source, provide a link to the Creative Commons license, and indicate if changes were made.

\section{References}

Al-Shammary AAG, Kouzani AZ, Kaynak A, Khoo SY, Norton M, Gates W (2018) Soil bulk density estimation methods: a review. Pedosphere 28:581-596. https://doi.org/10.1016/ S1002-0160(18)60034-7

Atallah T, Sitt K, El Asmar E, Bitar S, Ibrahim L, Khatib MN, Darwish T (2015) Effect of abandonment of olive orchards on soil organic carbon sequestration in Mediterranean Lebanon. Soil Res 53:745-752. https://doi.org/10.1071/ SR14170

Bouyoucos GJ (1962) Hydrometer method improved for making particle size analyses of soils. Agron J 54:464-465. https:// doi.org/10.2134/agronj1962.00021962005400050028x

Brunetti G, Plaza C, Senesi N (2005) Olive pomace amendment in mediterranean conditions: effect on soil and humic acid properties and wheat (Triticum turgidum L.) yield. J Agric Food Chem 53:6730-6737. https://doi.org/10.1021/ jf050152j

Cabrera F, Martín-Olmedo P, López R, Murillo JM (2005) Nitrogen mineralization in soils amended with composted olive mill sludge. Nutr Cycl Agroecosyst 71:249-258. https://doi.org/10.1007/s10705-004-6373-3

Da Rocha Junior PR, Soares ML, Ribeiro IG, Da Costa ASV, Donagemma GK, Mendonça EDS (2014) Soil carbon stock in silvopastoral system, pasture and sugarcaneculture. Idesia Arica 32:35-42. https://doi.org/10.4067/S071834292014000100005

Eichhorn MP, Paris P, Herzog F, Incoll LD, Liagre F, Mantzanas K, Mayus M, Moreno G, Papanastasis VP, Pilbeam DJ, Pisanelli A, Dupraz C (2006) Silvoarable systems in Europe-past, present and future prospects. Agrofor Syst 67:29-50. https://doi.org/10.1007/s10457-005-1111-7

FAO (2015) Soils help to combat and adapt to climate change by playing a key role in the carbon cycle. In: Fact sheet 2015 international year of soils

Fornara DA, Olave R, Burgess P, Delmer A, Upson M, McAdam J (2018) Land use change and soil carbon pools: evidence from a long-term silvopastoral experiment. Agrofor Syst
92:1035-1046. https://doi.org/10.1007/s10457-017-01243

GAL Bradanica (2013) Progetto pilota per la realizzazione di un impianto di utilizzazione delle acque reflue, Piano di Sviluppo Locale 2007/2013 Allegato 3 Scheda tecnicoscientifica

García-Ruiz R, Ochoa MV, Hinojosa MB, Gómez-Muñoz B (2012) Improved soil quality after 16 years of olive mill pomace application in olive oil groves. Agron Sustain Dev 32:803-810. https://doi.org/10.1007/s13593-011-0080-7

Gilbert N (2012) One-third of our greenhouse gas emissions come from agriculture. Nat News. https://doi.org/10.1038/ nature.2012.11708

Gordon A, Thevathasan N (2006) How much Carbon can be stored in Canadian Agroecosystems Using a Silvopastoral Approach? In: Mosquera-Losada M, McAdam J, RigueiroRodríguez A (eds) Silvopastoralism and sustainable land management. CABI Publishing, Wallingford, pp 210-219

Haile SG, Nair VD, Nair PKR (2010) Contribution of trees to carbon storage in soils of silvopastoral systems in Florida, USA. Glob Change Biol 16:427-438. https://doi.org/10. 1111/j.1365-2486.2009.01981.x

INFC (2005) Inventario Nazionale delle Foreste e dei Serbatoi Forestali di Carbonio. Ministero delle Politiche Agricole Alimentari e Forestali, Ispettorato Generale-Corpo Forestale dello Stato. Consiglio per la Ricerca e Sperimentazione in Agricoltura Unità di ricerca per il Monitoraggio e la Pianificazione Forestale (CRA-MPF)

IPCC (2000) Land use, land-use change, and forestry: summary for policymakers: a special report of the Intergovernmental Panel on Climate Change. WMO (World Meteorological Organization): UNEP (United Nations Environment Programme), Geneva

IPCC (2013) Stocker TF, Qin D, Plattner G-K, Tignor MMB, Allen SK, Boschung J, Nauels A, Xia Y, Bex V, Midgley PM (eds) Climate change 2013: the physical science basis. Summary for policymakers. Working group I contribution to the 5th assessment report of the intergovernmental panel on climate change

Janssens IA, Freibauer A, Ciais P, Smith P, Nabuurs G-J, Folberth G, Schlamadinger B, Hutjes RWA, Ceulemans R, Schulze E-D, Valentini R, Dolman AJ (2003) Europe's terrestrial biosphere absorbs 7 to $12 \%$ of European Anthropogenic $\mathrm{CO}_{2}$ Emissions. Science 300:1538-1542. https://doi.org/10.1126/science.1083592

Killham K (1994) Soil ecology. Cambridge University Press, Cambridge

Kottek M, Grieser J, Beck C, Rudolf B, Rubel F (2006) World Map of the Köppen-Geiger climate classification updated. Meteorol Z 15:259-263. https://doi.org/10.1127/09412948/2006/0130

Kutsch W, Heinemeyer A, Bahn M (eds) (2010) Soil carbon dynamics: an integrated methodology. Cambridge University Press, Cambridge

Lal R (2005) Forest soils and carbon sequestration. For Ecol Manag 220:242-258. https://doi.org/10.1016/j.foreco. 2005.08.015

Lee J, Hopmans JW, Rolston DE, Baer SG, Six J (2009) Determining soil carbon stock changes: simple bulk density corrections fail. Agric Ecosyst Environ 134:251-256. https://doi.org/10.1016/j.agee.2009.07.006 
Liao K, Wu S, Zhu Q (2016) Can soil pH be used to help explain soil organic carbon stocks? CLEAN 44:1685-1689. https:// doi.org/10.1002/clen.201600229

López-Piñeiro A, Albarrán A, Nunes JMR, Barreto C (2008) Short and medium-term effects of two-phase olive mill waste application on olive grove production and soil properties under semiarid mediterranean conditions. Bioresour Technol 99:7982-7987. https://doi.org/10.1016/ j.biortech.2008.03.051

Lozano-García B, Parras-Alcántara L (2014) Variation in soil organic carbon and nitrogen stocks along a toposequence in a traditional mediterranean olive grove. Land Degrad Dev 25:297-304. https://doi.org/10.1002/ldr.2284

Lozano-García B, Parras-Alcántara L, Cantudo-Pérez M (2016) Land use change effects on stratification and storage of soil carbon and nitrogen: application to a Mediterranean nature reserve. Agric Ecosyst Environ 231:105-113. https://doi. org/10.1016/j.agee.2016.06.030

Mohamad RS, Verrastro V, Al Bitar L, Roma R, Moretti M, Al Chami Z (2016) Effect of different agricultural practices on carbon emission and carbon stock in organic and conventional olive systems. Soil Res 54:173-181. https://doi.org/ 10.1071/SR14343

Montanaro G, Tuzio AC, Xylogiannis E, Kolimenakis A, Dichio B (2017a) Carbon budget in a Mediterranean peach orchard under different management practices. Agric Ecosyst Environ 238:104-113. https://doi.org/10.1016/j.agee. 2016.05.031

Montanaro G, Xiloyannis C, Nuzzo V, Dichio B (2017b) Orchard management, soil organic carbon and ecosystem services in Mediterranean fruit tree crops. Sci Hortic 217:92-101. https://doi.org/10.1016/j.scienta.2017.01.012

Mosquera-Losada MR, Freese D, Rigueiro-Rodríguez A (2011) Carbon Sequestration in European Agroforestry Systems. In: Kumar BM, Nair PKR (eds) Carbon sequestration potential of agroforestry systems: opportunities and challenges. Springer, Dordrecht, pp 43-59

Nair PKR, Nair VD, Kumar BM, Haile SG (2009) Soil carbon sequestration in tropical agroforestry systems: a feasibility appraisal. Environ Sci Policy 12:1099-1111. https://doi. org/10.1016/j.envsci.2009.01.010

Nieto OM, Castro J, Fernández E, Smith P (2010) Simulation of soil organic carbon stocks in a Mediterranean olive grove under different soil-management systems using the RothC model. Soil Use Manag 26:118-125. https://doi.org/10. 1111/j.1475-2743.2010.00265.x

Nieto OM, Castro J, Fernández-Ondoño E (2013) Conventional tillage versus cover crops in relation to carbon fixation in Mediterranean olive cultivation. Plant Soil 365:321-335. https://doi.org/10.1007/s11104-012-1395-0

Parras-Alcántara L, Lozano-García B (2014) Conventional tillage versus organic farming in relation to soil organic carbon stock in olive groves in Mediterranean rangelands (southern Spain). Solid Earth 5:299-311. https://doi.org/ $10.5194 / \mathrm{se}-5-299-2014$

Piotrowska A, Iamarino G, Rao MA, Gianfreda L (2006) Shortterm effects of olive mill waste water (OMW) on chemical and biochemical properties of a semiarid Mediterranean soil. Soil Biol Biochem 38:600-610. https://doi.org/10. 1016/j.soilbio.2005.06.012

Pisanelli A, Ecosse A, Perali A, Scarascia Mugnozza G, Cannata F, Olimpieri G, Paris P (2006) I Sistemi agroforestali in Europa. Alberi E Territ 5:12

Proietti S, Sdringola P, Desideri U, Zepparelli F, Brunori A, Ilarioni L, Nasini L, Regni L, Proietti P (2014) Carbon footprint of an olive tree grove. Appl Energy 127:115-124. https://doi.org/10.1016/j.apenergy.2014.04.019

Regione Umbria (2017) Olivicoltura. http://www.regione. umbria.it/agricoltura/olivicoltura. Accessed 17 Jan 2019

Rioux J (2012) Opportunities and challenges of promoting agroforestry for climate change mitigation: a case-study of the Mitigation of Climate Change in Agriculture (MICCA) pilot project in Tanzania. Nat Faune 26:63-68

Roig A, Cayuela ML, Sánchez-Monedero MA (2006) An overview on olive mill wastes and their valorisation methods. Waste Manag 26:960-969. https://doi.org/10. 1016/j.wasman.2005.07.024

Saviozzi A, Levi-Minzi R, Cardelli R, Biasci A, Riffaldi R (2001) Suitability of moist olive pomace as soil amendment. Water Air Soil Pollut 128:13-22. https://doi.org/10. 1023/A:1010361807181

Schroeder P (1994) Carbon storage benefits of agroforestry systems. Agrofor Syst 27:89-97. https://doi.org/10.1007/ BF00704837

Takimoto A, Nair VD, Nair PKR (2009) Contribution of trees to soil carbon sequestration under agroforestry systems in the West African Sahel. Agrofor Syst 76:11-25. https://doi. org/10.1007/s10457-008-9179-5

Tonon G, Sohi S, Francioso O, Ferrari E, Montecchio D, Gioacchini P, Ciavatta C, Panzacchi P, Powlson D (2010) Effect of soil $\mathrm{pH}$ on the chemical composition of organic matter in physically separated soil fractions in two broadleaf woodland sites at Rothamsted, UK. Eur J Soil Sci 61:970-979. https://doi.org/10.1111/j.1365-2389.2010. 01310.x

Udawatta RP, Jose S (2011) Carbon sequestration potential of agroforestry practices in temperate North America. In: Kumar BM, Nair PKR (eds) Carbon sequestration potential of agroforestry systems: opportunities and challenges. Springer, Dordrecht, pp 17-42

UNFCCC (2015) Adoption of the Paris agreement. Report no. FCCC/CP/2015/L.9/Rev.1

Vicente-Vicente JL, García-Ruiz R, Francaviglia R, Aguilera E, Smith P (2016) Soil carbon sequestration rates under Mediterranean woody crops using recommended management practices: a meta-analysis. Agric Ecosyst Environ 235:204-214. https://doi.org/10.1016/j.agee.2016.10.024

Publisher's Note Springer Nature remains neutral with regard to jurisdictional claims in published maps and institutional affiliations. 